\title{
The Use of Oil Palm Trunks for Wood Products
}

\author{
Fruehwald Arno ${ }^{1, a^{*}}$, Fruehwald-Koenig Katja ${ }^{2, b}$ \\ ${ }^{1}$ PalmwoodNet Detmold, Germany and Palmwood R+D, Engelbergerstr. 19, 79106 Freiburg, \\ Germany \\ ${ }^{2}$ University of Applied Sciences Ostwestfalen-Lippe, Department 7: Production and \\ Management, Liebigstr. 87, 32657 Lemgo, Germany \\ aarno.fruehwald@gmx.de, fruehwald@palmwood.de, bkatja.fruehwald@hs-owl.de
}

Keywords: oil palm trunks, palm wood, processing, palm products

\begin{abstract}
Worldwide, oil palms cover an area of nearly 25 million ha with over 75 \% located in Asia. After 25 years of age, the palms are felled and replaced due to declining oil production. The average annual total volume of trunks from plantation clearings amounts to more than 100 million $\mathrm{m}^{3}$. Like all other biomass, the trunks remain on the plantation site for nutrient recycling. But this leads to increased insect and fungi populations causing problems for the new palm generation. Many regions where oil palms grow currently suffer from a decline in timber harvested from their tropical forests. An extensive project, involving partners from both $\mathrm{R}+\mathrm{D}$ and industry, is studying the possibility of improving the use of oil palm trunks to manufacture marketable timber products. The consortium consists of some 20 partners mainly from Germany, Malaysia, and Thailand. Areas of development are: harvesting and storage of trunks, sawmilling, drying, processing into various products like solid wood-based panels (block-board), flash doors, furniture elements as well as CLT and gluelam for the building sector. All sectors have shown remarkable success.
\end{abstract}

\section{Introduction}

The availability of timber from tropical forests is steadily declining due to over logging and measures taken towards sustainable forest management and conservation of tropical forests. In Asia the demand for wooden products is rising due to a growing population and greater economic development. The declining wood supply from tropical forests in Southeast Asia is partly being compensated for by imported timber (i.e. from North and Latin Americas, Australia, New Zealand, Europe), and new fiber sources are also being developed. Rubberwood from Indonesia, Malaysia, and Thailand has found its way into the markets and the use of bamboo is rapidly increasing. Rubberwood, however, is limited in quantity, because rubber plantations are being converted into oil palm plantations due to improved economy. Fast growing forest trees like albizzia (Albizia falcataria (L.) Fosberg) are being promoted but can hardly fill the increasing supply shortage.

Palms have long been a source of fiber for manufacturing products, but mainly fibers from husks (i.e. coconut fibers) or, to a lesser extent, from palm fronds or fruit bunches. Also nut shells are often used as fillers of (activated) coal. The trunks of coconut palms are widely used as building material, for furniture and crafts. A good example is in the Philippines were coco-wood has an important market share. But utilization is performed more locally in small workshops with partly inferior processing techniques and tools, resulting in low quality and more simple products. Processing is difficult as density of coconut trunks is high and hard vascular bundles, ash and silica causes high tool wear. The trunks from date palms generally have lower and evenly distributed density making processing easier. Nevertheless, date palms are less available, 
because as their growing area is much smaller (Table 1 and Table 2) and the average age of a palm is high, resulting in less felled palms.

Oil palms (Elais guineensis JACQ.) were introduced in Asia around 100 years ago. With initially limited distribution, the plantation areas have grown steadily since around the 1970s, first in Malaysia, later in Thailand and Indonesia. Table 1 shows the estimates for the plantation area, which is worldwide above 25 million ha with a growing tendency, especially in Indonesia and some Latin-American countries. Experts estimate global coverage will range between 30 to 40 million ha in the year 2030.

Table 1: Palms with potential for industrial conversion of trunks into products.

\begin{tabular}{|l|c|c|c|c|c|}
\hline palms & $\begin{array}{c}\text { world area } \\
\text { [million ha] }\end{array}$ & $\begin{array}{c}\text { number of } \\
\text { palms [million] }\end{array}$ & $\begin{array}{c}\text { rotation } \\
\text { period } \\
\text { [years] }\end{array}$ & $\begin{array}{c}\text { number of } \\
\text { available palms } \\
\text { [million] }\end{array}$ & $\begin{array}{c}\text { available } \\
\text { million } \mathrm{m}^{3} \\
\text { [palm } \\
\text { trunks per } \\
\text { year] }\end{array}$ \\
\hline oil palm & 25 & 3,000 & 25 & 120 & 180 \\
coconut palm & 12 & 1,200 & 50 & 24 & 40 \\
date palm & 0.8 & 110 & 55 & 2 & 3 \\
\hline
\end{tabular}

Table 2: Main growing countries for palms and areas in million ha (various sources).

\begin{tabular}{|lrlcll|}
\hline oil palm & \multicolumn{3}{c|}{ coconut palm } & date palm \\
\hline Indonesia & 13.0 & Indonesia & 4.0 & Iran & 0.22 \\
Malaysia & 5.0 & Philippines & 3.5 & Iraq & 0.21 \\
Nigeria & 3.5 & India & 2.0 & UAE & 0.16 \\
Thailand & 1.0 & Brasil & 0.5 & S. Arabia & 0.04 \\
\hline World & $>25.0$ & world & $\sim 12.0$ & world & $\sim 1.0$ \\
\hline
\end{tabular}

Past attempts to use oil palm trunks (OPT) as a supplement or substitute for tropical timber in product manufacturing failed due to the palms' different material properties and processing behavior compared to traditional wood species. Intensive R+D, especially in Malaysia [i.e. 1, 2, $3,4]$, has provided a clearer understanding of the material (structure, mechanical, and chemical properties) and worked to test manufacture of products. With the exception of plywood manufactured in Malaysia (some $50.000 \mathrm{~m}^{3} / \mathrm{y}$ ), all efforts towards semi industrial or industrial use proved unsuccessful. Product quality, processing of the material (i.e. sawing, planing, drying) and logistics / supply did not meet high enough standards to make to a manufacturing break through.

Yet, given the tremendous supply of OPT (180 million $\mathrm{m}^{3} / \mathrm{y}$, see Table 1 ) and the rapid decline in common timber stocks, the need to launch a "new start in OPT utilization" is obvious. After several years of scientific oriented material research in various German and Asian universities and research centers, a consortium was founded consisting of five industrial core partners and some 20 associated partners from academia and industry in Germany resp. Europe, Malaysia and Thailand. Information about the consortium can be found on the project website, www.palmwoodnet.com. 


\section{OPT Harvesting: Potentials and Logistics}

After 25 years of age, oil palms are felled and replaced due to declining oil production (remarkably less than $5 \mathrm{t} / \mathrm{ha}$ palm oil). Plantations are cleared on plots ranging from only a few hectares to up to 100 ha (or more) depending on ownership, age distribution, and site conditions. Generally, clearing starts at the beginning of the dry season, the sites are prepared for replanting at the beginning of the following wet season. Traditionally, most of the biomass from the clearing was piled up in rows and burned (with the help of sprayed diesel) at the end of the dry season. The main aim was to avoid pests caused by fungi (Ganoderma) and beetles. Today, most countries have introduced a zero-burning-policy so now the trunks are chipped and evenly distributed (together with fronds and leaves) on the site ore piled up in rows of 10 or $20 \mathrm{~m}$ distance (in-between the rows for re-planting) to let the material rot.

For the OPT volume to be harvested for use, PalmwoodNet developed a concept for removing some $70 \mathrm{~m}^{3}$ of OPT per ha (from $150-180 \mathrm{~m}^{3} / \mathrm{ha}$ in total) for reasons of nutrient management (among others $\mathrm{K}, \mathrm{P}, \mathrm{Ca}, \mathrm{N}, \mathrm{Mg}$ ) and soil quality. Normally, the palms are felled by "pushfelling" where an excavator pushes the palms to the ground and chips it into pieces between 20 $40 \mathrm{~cm}$ in length. The felling technique will be modified to secure less or no damage to the trunks. The discrepancy between felling within two dry periods per year of $2-3$ months only and a continuous supply of processing mills must be bridged by either extension of the plantation clearing periods and / or appropriate storage techniques for the trunks. Intensive laboratory research followed by field tests has led to storage techniques and conservation of the trunk cross cut sections with "green chemicals" in order to avoid rapid and intensive manifestation of mold followed by stain of the wood. The results have shown little damage to the wood even after storage of $2-3$ months; the techniques are also very cost effective.

\section{Properties of Oil Palm Wood}

A large number of publications describe the basic properties of oil palm wood, but quite often as secondary literature. Experimental research is not always systematic in terms of material selection and methods applied. In the following, a general overview of the properties is given, some references are made. The partners of PalmwoodNet have dealt with material properties relevant for processing and use of the palm wood.

Density variation: As a monocot, the density varies remarkably along the trunk diameter and along the trunk length. The outer peripheral zones (at the trunk base) show dry densities of 0.5 $0.7 \mathrm{~g} / \mathrm{cm}^{3}$ caused by high density fibers / fiber cups of the vascular bundles (VB) and high share of the VB of the wood volume. The more inner / central part of the trunk show densities between $0.2-0.3 \mathrm{~g} / \mathrm{cm}^{3}$ (less VB). Fig. 1 and 2 show typical density distribution. Along the trunk axis, the density decreases to $0.4-0.5 \mathrm{~g} / \mathrm{cm}^{3}$ at the periphery and $0.15-0.25 \mathrm{~g} / \mathrm{cm}^{3}$ in the inner zone due to younger age of the cells. The cell walls show "secondary growth" of their thickness by additional cell wall layers with the age. This might be one of the reasons for the higher density of coconut wood compared to oil palm wood as coconut palms are only harvested at the age of 50+. 


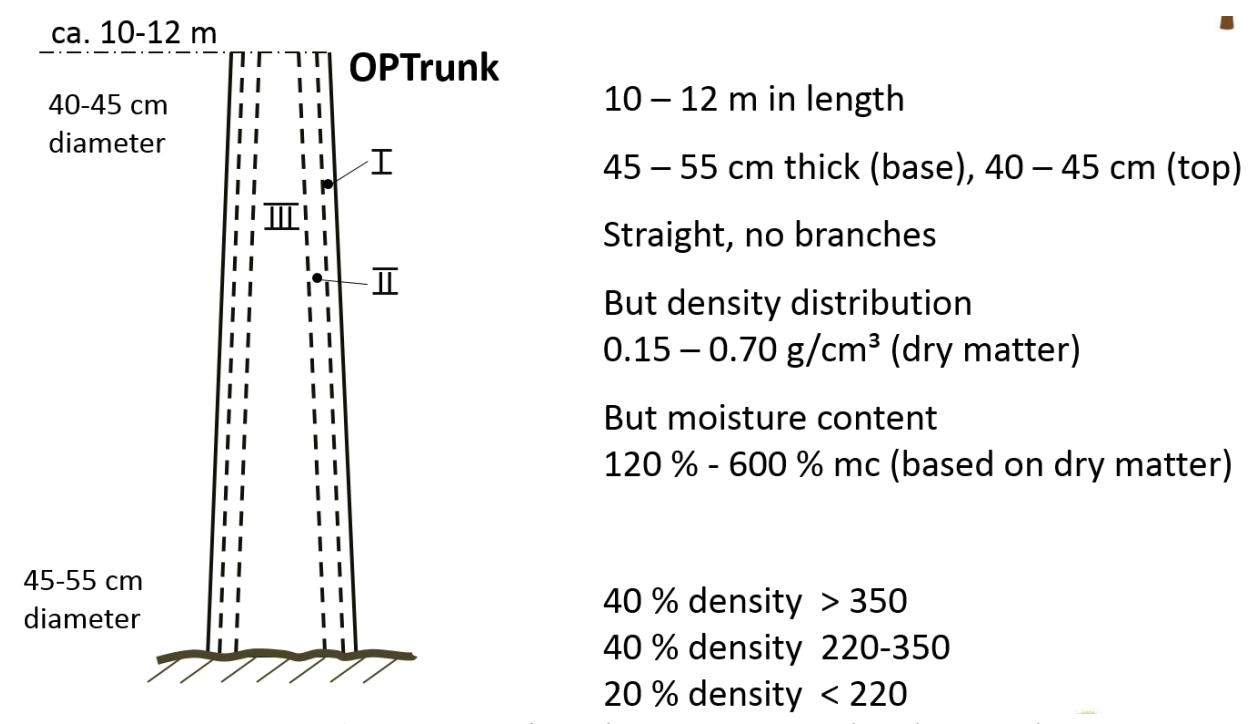

Figure 1: Density distribution in an oil palm trunk.

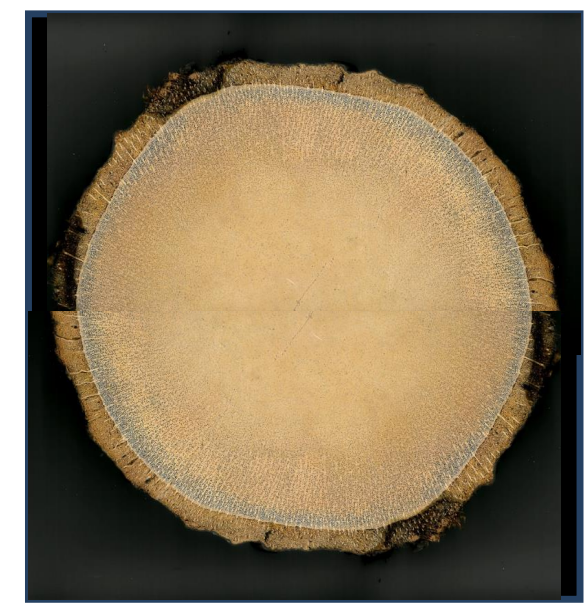

Figure 2: Cross section of an oil palm trunk.

Moisture content: For reasons of physiology (to bridge water shortage during dry seasons) the tissue of OPT contains a high percentage of water - generally the parenchyma cells show almost maximum moisture content (which depends on the density). Fig. 3 shows moisture contents (based on dry density) of between $>100 \%$ (peripheral zone, base of trunk) and $600 \%$ (inner zone, top of the trunk). The high moisture content results in the high weight of the trunks (logistics), risks of mechanical damages and difficult, long and expensive drying. OPT shows an average moisture content (whole trunk) of $200-250 \%$ whereas coconut trunks show only $50 \%$ resp. $350 \%$ moisture content (densities 0.75 resp. 0.35 g/ $\mathrm{cm}^{3}$ ) [5]. 


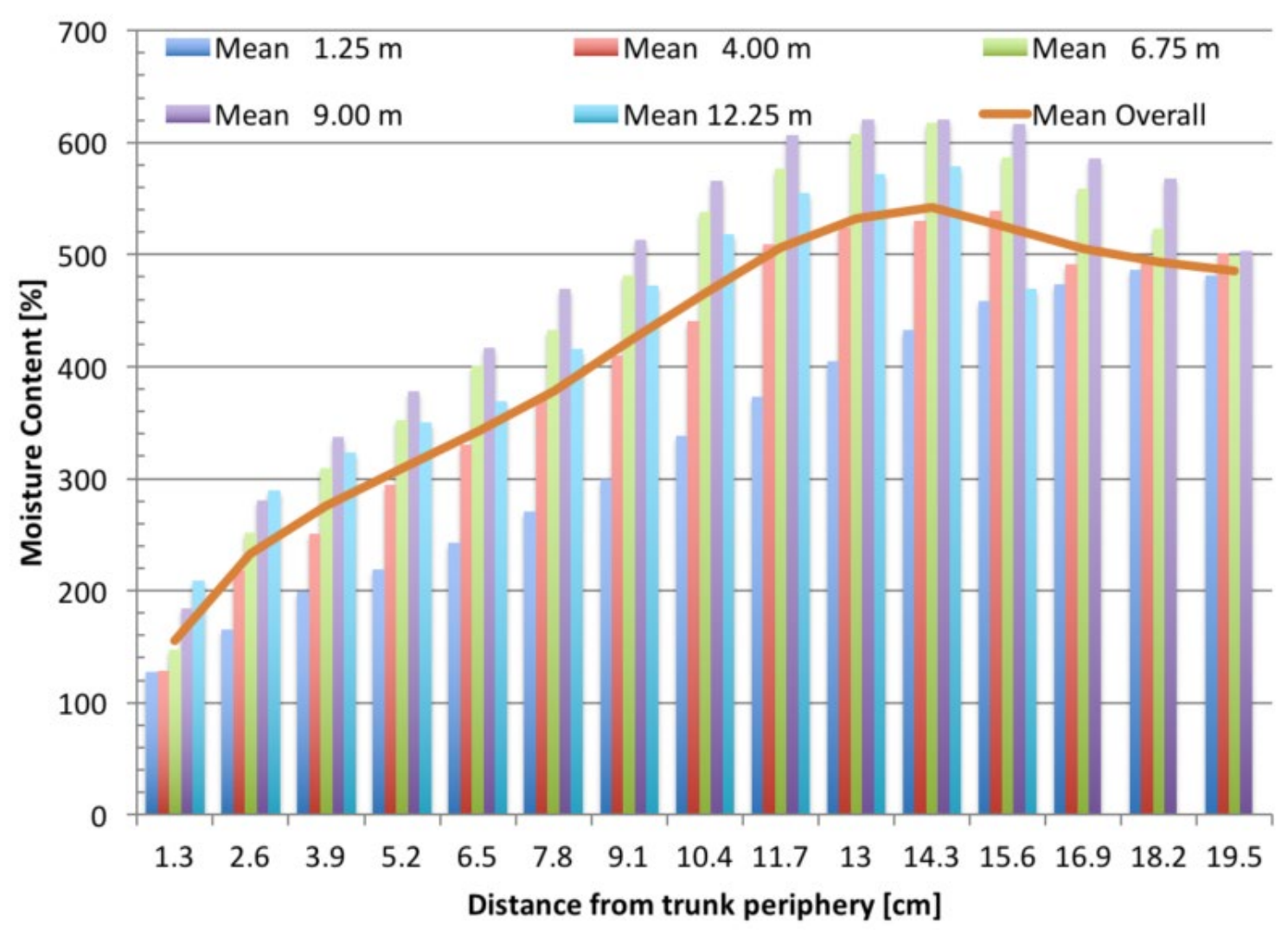

Figure 3: Moisture content distribution [13].

Ash and silica content: All palms show higher ash and silica contents compared to most common timber species (Table 3). This results in increased tool wear during processing. Oil palm wood contains ash up to $2.0 \%$ of dry mass (especially potassium content is high) and silica of up to $0.7 \%$. For silica these values are higher compared to coconut palms and date palms [6]. All palms (as well as bamboo) require special tools and tool materials for high quality processing (i.e. sawing across fiber direction) and sufficient tool life. PalmwoodNet places strong emphasis on tool development (together with adopted processing and process parameters) and has achieved remarkable results $[7,8]$.

Table 3: Mineral contents and pH-values (average values) of date palm and oil palm wood [6].

\begin{tabular}{|c|c|c|c|c|}
\hline & oil palm & date palm & pine & oak \\
\hline $\mathrm{pH}$ & 4.2 & 5.1 & 3.4 & 3.4 \\
\hline $\operatorname{ash}[\%]^{1)}$ & 1.8 & 2.2 & 0.3 & 0.5 \\
\hline silica $[\%]^{1)}$ & 0.56 & 0.18 & 0.04 & 0.01 \\
\hline density $\left[\mathrm{g} / \mathrm{cm}^{3}\right]^{2)}$ & 0.43 & 0.64 & 0.52 & 0.70 \\
\hline
\end{tabular}

Hygroscopicity: As with all timber species, oil palm wood shows hygroscopic behavior which means that the moisture content is in equilibrium with the moisture conditions of the surrounding air. Bound water level depends on the composition of the main chemicals. As [1] and [2] have shown, the level of cellulose, hemicellulose and lignin is in the same order compared to many 
common timber species. For moisture content between $15 \%$ and $30 \%$ the cell wall structure is important as "liquid water" is already captured in small caverns. Generally, oil palm wood should have similar sorption isotherms as common timber species. One "big problem" is the content of sugars in the wood, like glucose and sucrose, which absorb additional water from the air. This results in increased equilibrium moisture content at higher relative humidity levels. PalmwoodNet partners have studied this (well known) phenomenon and have developed measures to cope with this problem.

Swelling/shrinkage: In the past little systematic research was done on the shrinkage of oil palm wood. What is described in literature [i.e. 9] are values for maximum shrinkage from green to bone dry. The values indicate that under these test conditions cell collapse can occur which must be excluded from "normal shrinkage". [10] has given values for volume shrinkage between $10 \%$ and $23 \%$ for the various wood densities. He also mentioned the problem of cell collapse. For the use of oil palm wood-based products the shrinkage/swelling factors related to the variation of humidity should be known. PalmwoodNet partners have set up a comprehensive test program to study this aspect. Generally, oil palm wood is isotropic in radial and tangential directions of the trunk. This means that shrinkage and swelling is similar in both directions.

Mechanical properties: The mechanical properties elasticity and strength are very much influenced by the structure of oil palm wood. Along the trunk axis, the vascular bundles (having high-density fiber caps) "dominate" the properties, especially tension. Across trunk axis, the low-density parenchyma is responsible for much lower property values compared to along the trunk axis. Mechanical properties play a significant role in the design and use of products as well as for processing of the wood. In a joint effort, PalmwoodNet partners have analyzed "areas of necessary knowledge for product design for use and material processing". Related to the intended products (see below) and the developed processes for product manufacture (sawing, planning, moulding, sanding, glueing, drying etc.) the necessary set of properties were studied. With this, products and processes can be modeled and designed. To give a rough idea about mechanical properties, the information in Table 4 was compiled from literature.

Table 4: Mechanical properties of oil palm wood and date palm wood in comparison with other wood species [11]

\begin{tabular}{|l|c|c|c|c|c|c|c|}
\hline & oil palm & $\begin{array}{c}\text { coconut } \\
\text { palm }\end{array}$ & $\begin{array}{c}\text { date } \\
\text { palm }\end{array}$ & spruce & beech & poplar & $\begin{array}{c}\text { rubber- } \\
\text { wood }\end{array}$ \\
\hline density [g/cm ${ }^{3}$ ] & $0.22-$ & $0.25-$ & 0.41 & $0.30-$ & $0.49-$ & $0.36-$ & 0.64 \\
0.55 & 0.85 & 0.88 & 0.56 & 0.53 \\
\hline MOE [MPa] & $\begin{array}{c}800- \\
8,000\end{array}$ & 5,300 & $\begin{array}{c}1,719- \\
2,745\end{array}$ & 11,000 & 16,000 & 8,300 & 8,800 \\
\hline MOR [MPa] & $8-45$ & 36 & $11-23$ & 66 & 105 & 76 & 58 \\
\hline $\begin{array}{l}\text { compression } \\
\text { strength [MPa] }\end{array}$ & $5-25$ & 24 & $6-10$ & 43 & 53 & 36 & 26 \\
\hline hardness [N] & $\begin{array}{c}350- \\
2,450\end{array}$ & 4,230 & 2,000 & 2,140 & 5,650 & 2,500 & 4,320 \\
\hline
\end{tabular}




\section{Products made from Oil Palm Wood}

Since about 1980, several attempts have been made to use oil palm wood for manufacturing products. Especially in Malaysia with its large plantation areas and reduced logging in natural forests (particularly in Peninsula Malaysia) OPW became an obvious source for bridging the demand and supply gap for wood and wood products. It was inspired by the market success achieved with rubberwood-based products. The main players were the Forest Research Institute Malaysia (FRIM), University Putra Malaysia (UPM) and Malaysia Palm Oil Board (MPOB) and the former Malaysian Oil Palm Research Centre. The work was twofold: on one side the research focused on material properties, on the other side the development of processes and products. Various conferences in Malaysia and Southeast Asia aimed to distribute the findings. Examples of state-of-the-art reports are [1, 2, 3, 4]. Most effort was directed towards products like furniture, plywood, chipboard, and fiberboard. When evaluating this work, it becomes clear that it was extremely difficult to achieve progress similar to the rubberwood success. The material properties of oil palm wood differ so greatly from common timber species (including rubberwood), and the methods of processing material also varies significantly due to structure, density variation, drying, inhomogeneity of mechanical properties etc. The product quality therefore was much below market expectations; quality in the sense of appearance, durability, design and working quality. Various attempts have been made in Malaysia to support the plywood and composite panels industry. Reports like [12] and [4] describe achievements, but also many hurdles towards broad commercialization. The main drawback certainly was processing of the oil palm wood. Because of the lack of appropriate processes and tools and the focus on "traditional products" most of the attempts failed or had very little success (plywood with the use of oil palm veneer as core layers).

After 2005, several research institutions, universities and engineering companies in Germany with knowledge in coconut $\mathrm{R}+\mathrm{D}$ started looking deeper into material properties, possible product design and identified areas for process and tool development. In 2013 discussions started aimed at establishing a network with members of $\mathrm{R}+\mathrm{D}$ institutions and engineering companies (woodworking machines) for comprehensive development work. In 2015 PalmwoodNet was officially founded and started development activities. The products in focus are panels based on solid wood and veneer design, multilayer solid wood composites, door panels, acoustic panels, building elements like glued laminated timber and solid wood multi-layer panels. Fig. $4-8$ show some examples of the developed products for which processes are already being developed as well. 

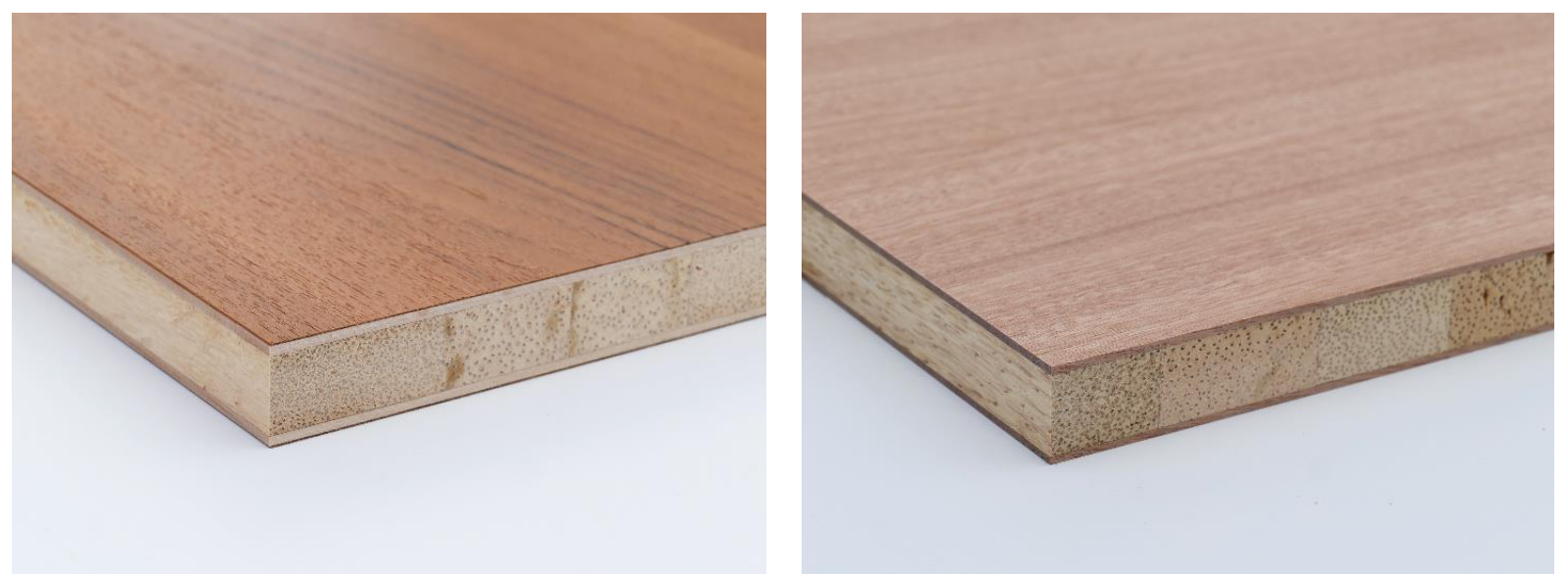

Figure 4: Blockboard, core from low density material (overall density $0.22-0.30 \mathrm{~g} / \mathrm{cm}^{3}$ ).
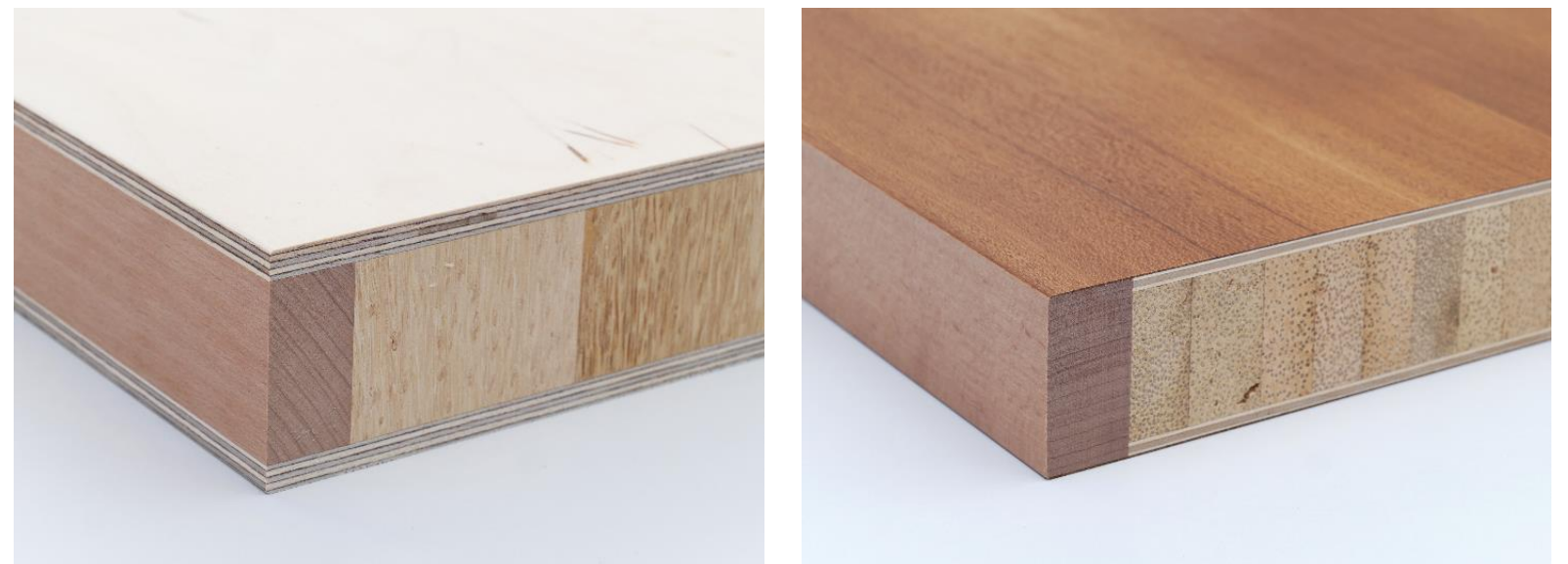

Figure 5: Door panel.

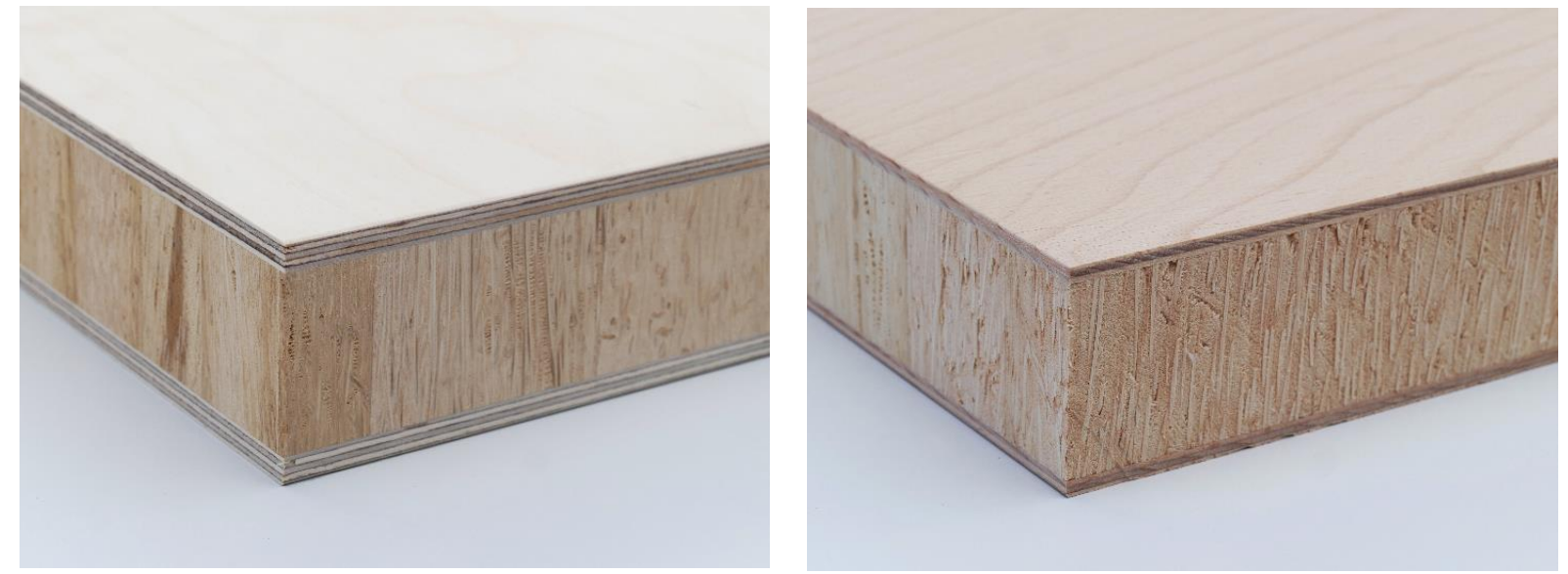

Figure 6: Sandwich Panel (middle layer vertical). 

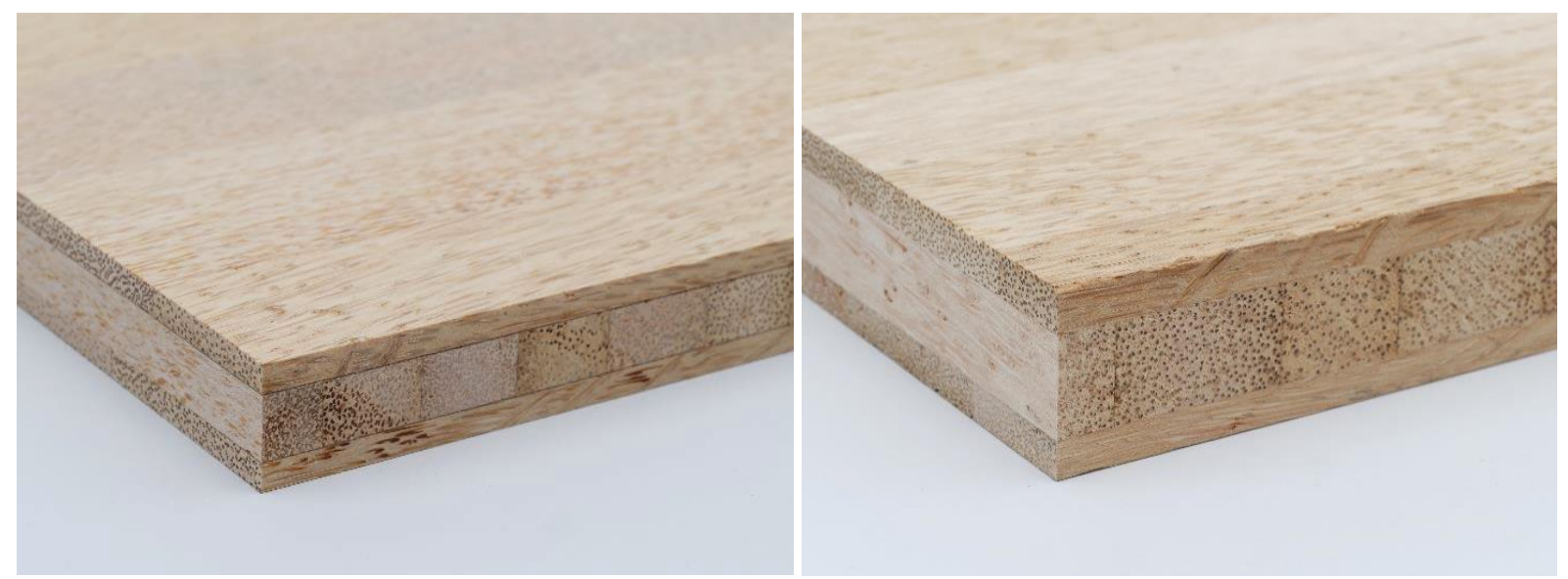

Figure 7: 3-Layer-Panel from mixed density.
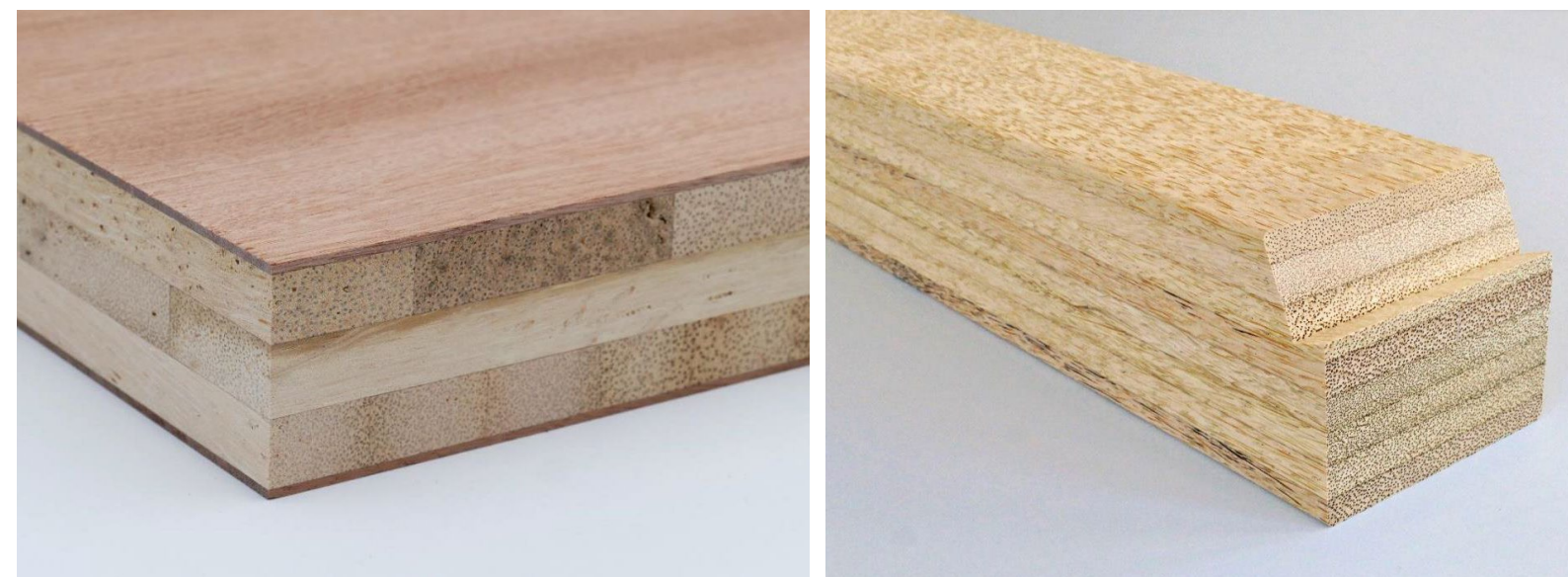

Figure 8: left: 3-Layer Solid Wood Panel (CLT) with core from low and medium density material; right: Glued-Laminated Timber (Gluelam) from high density material.

PalmwoodNet consists of five core partners: Moehringer Sawmill Technology, Leitz Woodworking Tools Technology, Minda Engineering (Panels and Beams), Jowat Adhesives and Palmwood R+D Engineering. More than 20 associated partners from academia in Germany, Malaysia, and Thailand as well as industry partners from Germany, Italy, and Malaysia have contributed to development in all relevant sectors. Fig. 9 shows a rough outline of the areas of work.

\begin{tabular}{llll}
$\begin{array}{l}\text { availability } \\
\text { of resource }\end{array}$ & $\begin{array}{l}\text { basic properties } \\
\text { bio, chem, phys, tech }\end{array}$ & $\begin{array}{l}\text { primary, secondary } \\
\text { processing }\end{array}$ & $\begin{array}{l}\text { environmental, } \\
\text { energy aspects }\end{array}$ \\
\hline $\begin{array}{l}\text { harvesting, } \\
\text { locistics, storage }\end{array}$ & $\begin{array}{l}\text { use related properties } \\
\text { - customer, standards } \\
\text { - building regulations }\end{array}$ & $\begin{array}{l}\text { product design }+ \\
\text { engineering }\end{array}$ & $\begin{array}{l}\text { market issues, } \\
\text { certification }\end{array}$ \\
& &
\end{tabular}

Figure 9: Areas of concern for $R+D$ in palm wood utilization. 
Fig. 10 shows an overview on the key processes in oil palm wood utilization.

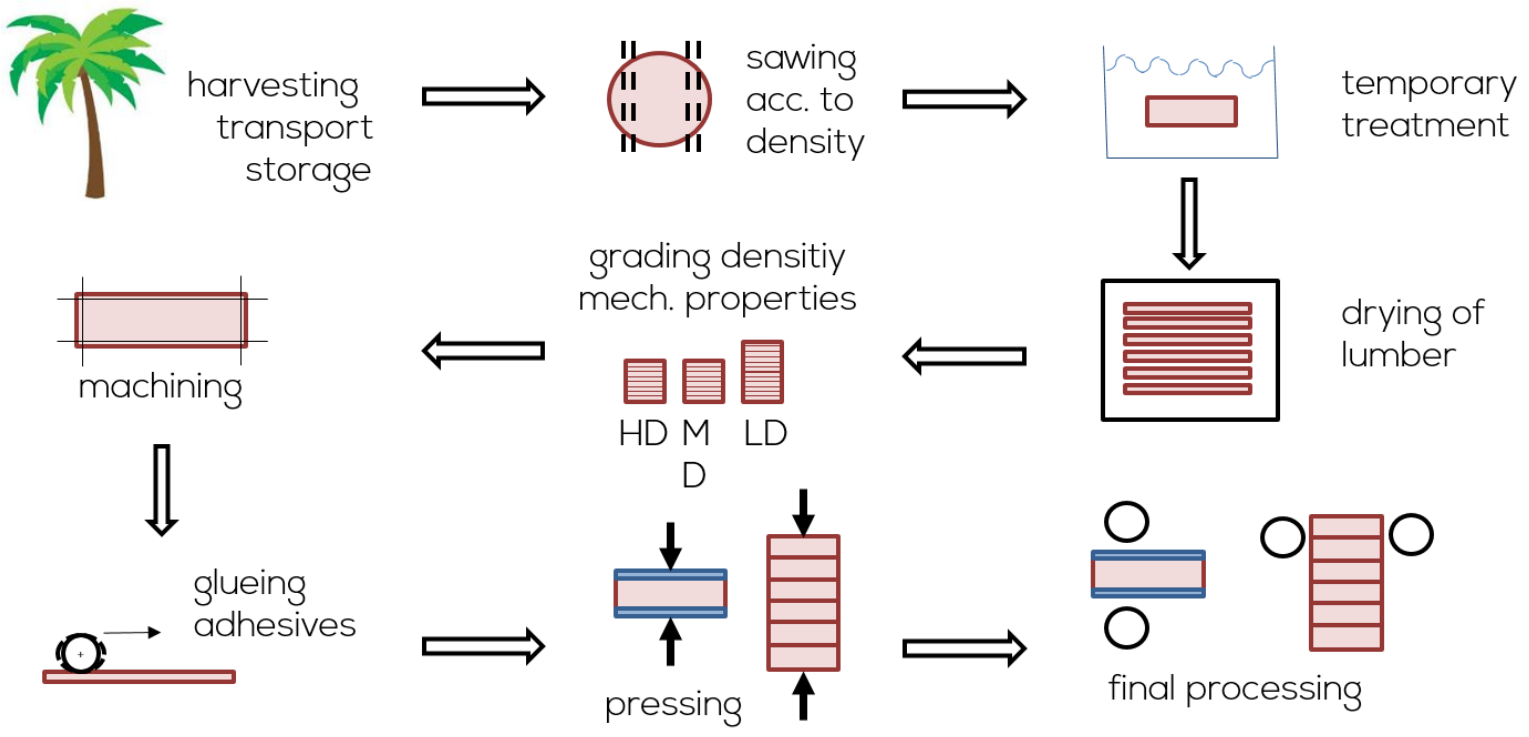

Figure 10: Key processes in palm wood utilization

The working principle is "easy": identify development needs, move the relevant experts towards solutions, test the new technologies, combine and optimize single processes and product design to complete manufacturing strategies.

\section{Concepts for Products and their Manufacturing}

Based on market studies for products, on technical product design, process development, supply with raw material and cost/revenue analysis several manufacturing strategies are being developed. These strategies include various product families, capacities, mix of products (or product families resp.) for improved raw material and capacity utilization, local aspects for supply and production sites as well as cost/benefit evaluation. The concepts developed are ready for implementation, adoption for local conditions and individual request is possible through computer-aided planning tools. The network will continue to develop industrial solutions on specific request which can include market and product specification, process design, integrated manufacturing together with existing wood processing mills etc.

Socio-economic aspects: Depending on the products in focus, capacity of production and standard of mechanization and automatization (PalmwoodNet favors the latest state of the art of technology) for each $200-400 \mathrm{~m}^{3}$ of OPT utilization one work-place for one year (1 WPy equals $200-400 \mathrm{~m}^{3} \mathrm{OPT}$ ) can be calculated. Including supply with other necessary material (glue etc.) and local supplies as well as sales chain to the final customer an equivalent of 1 WPy equals $100-150 \mathrm{~m}^{3}$ OPT is realistic. For a potential use of OPT in Malaysia (total availability some 200,000 ha/y replanting) of $10-15$ million $\mathrm{m}^{3}$ OPT per year this results in some 100,000 jobs. A certain number of these jobs will replace jobs in the timber industry using common species from tropical forests. 10 million $\mathrm{m}^{3}$ OPT may result in $3-4$ million $\mathrm{m}^{3}$ final products (material equivalents) having a production value of around $1.5-2$ billion Euro (including residue valorization). 
Ecological aspects: There are several aspects with ecological relevance:

a) OPT provides a substitute for timber from tropical forests or wood from plantations stocking on tropical forestland.

b) Using OPT for products (and partly for energy) reduces the high volume of trunk biomass being chipped on the replanting site. High biomass volume can cause a risk for fungi and beetle spread on the re-planting sites.

c) The use of wood-based products is known to have $\mathrm{CO}_{2}$-positive effects. Compared to the use of alternative materials, the use of wood results in less $\mathrm{CO}_{2}$-emissions - some $1 \mathrm{t} \mathrm{CO}_{2}$ per $1 \mathrm{~m}^{3}$ wood used. A rough calculation of the effects is given for Malaysia in Table 5.

d) OPT use contributes to the development of an increased sector bio-economy.

e)

\section{References}

[1] S. Khozirah, K.C. Khoo, A.R.M. Ali, Oil Palm Stem Utilization - Review of a research, Forest Research Institute Malaysia (FRIM) (1991).

[2] I. Wan Asma, K. Wan Rashidah, J. Rafidah, J. Khairul Azmi, As Good As Wood, Forest Research Institute Malaysia (FRIM), Kepong (2012).

[3] S.P. Chandak, I. Wan Asma, converting Waste Oil Palm Trees into a Resourve, FRIMUNEP Collaborative Project Report, Osaka, Japan (2012).

[4] MTIB, Palm Timber: A New Source of Material with Commercial Value (2015).

[5] A. Frühwald, R.D. Peek, M. Schulte, Utilization of Coconut Timber, Federal Research Centre for Forestry and Forest Products, Institute of Wood Physics and Mechanical Technology \& Institute of Wood Biology and Wood Protection, Hamburg (1992).

[6] T. Tufashi, Physical-Mechanical and Chemical Properties of the Wood of Oil palm and Date palm Trees, Bachelor Thesis at the University of Hamburg, Zentrum Holzwirtschaft (2013).

[7] S.P. Sukumaran, A. Kisselbach, F.Scholz, C. Rehm, Investigation of machinability of kiln dried oil palm wood with regard to production of solid wood products, in: M. Zbiec, K.

Orlowski, Proceedings of the International Wood Machining Seminar, Warsaw, Poland, 2017, pp. 131-142.

[8] S.P. Sukumaran, A. Kisselbach, F. Scholz, C. Rehm, J. Graef, Investigation of machinability of kiln dried oil palm wood with regard to production of solid wood products, Holztechnologie, 59-3 (2018) 19-31.

[9] E. Bakar, D. Hermawan, S. Karlina, O. Rachman, N. Rosdiana, Utilization of oil-palm trees as building and furniture materials (I): Physical and chemical properties, and durability of oilpalm wood, Journal Teknologi Hasil Hutan (Indonesia) 11-1 (1998) 1-12.

[10] S.H. Erwinsya, Improvement of Oil Palm Wood Properties Using Bioresin. PhD-Thesis at the Technical University Dresden, Fakultät für Forst-, Geo- und Hydrowissenschaften, Institut für Forstnutzung und Forsttechnik, Dresden (2008).

[11]W. Killmann, S.C. Lim, Anatomy and Properties of Oil Palm Stem, in: Proceedings National Symposium of Oil Palm By-Products, Kuala Lumpur, Malaysia (1985). 
[12]L.Y. Feng, A. Mokhtar, P.Md. Tahir, C.K. Kee, H.W. Samsi, Y.B. Hoong, Handbook of Oil Palm Trunk Plywood Manufacturing, Malaysian Timber Industry Board, Kuala Lumpur, Malaysia (2014).

[13] N. Kölli, Density and Moisture Distribution in Oil Palm Trunks from Peninsular Malaysia, BSc-Thesis at Hamburg University, Zentrum Holzwirtschaft (2016). 